\title{
POVERTY ALLEVIATION THROUGH SELF-SUSTAINING NEW ENTREPRENEURS PROGRAM: A CASE STUDY IN BANGLADESH
}

\author{
DOI: 10.17261/Pressacademia.2019.1160 \\ RJBM- V.6-ISS.4-2019(7)-p.306-314
}

MFM Amir Khashru', Chieh-Yu Lin²

${ }^{1}$ Chang Jung Christians University, PhD program in Business and Operations Management, Tainan, Taiwan amirkhashru1@gmail.com, ORCID: 0000-0002-9003-4161

${ }^{2}$ Chang Jung Christian University, Department of International Business, Tainan, Taiwan. jylin@mail.cjcu.edu.tw, ORCID: 0000-0003-3393-9674

Date Received: November 4, 2019

Date Accepted: December 20, 2019

To cite this document

Khashru, A., Lin, C.Y.,(2019). Poverty alleviation through self-sustaining new entrepreneurs program: a case study in Bangladesh. Research Journal of Business and Management (RJBM), V.6(4), p.306-314

Permemant link to this document: http://doi.org/10.17261/Pressacademia.2019.1160

Copyright: Published by PressAcademia and limited licenced re-use rights only.

\section{ABSTRACT}

Purpose- One of the significant challenges facing many countries in the world is poverty. Mass poverty and unemployment can be eliminated through entrepreneur development. This study focuses on introducing how the new entrepreneurs (NE) program can help poverty alleviation in Bangladesh.

Methodology- The case study was used to capture the NE program process and context. The data collection was done by in-depth interviews with respondents who are business owners of different small business.

Findings- The result of this study showed that the NP program has significant effect on poverty reduction in Bangladesh. The NP program is the process that provides trainees with knowledge, skills, and financial support to create a professional businessman for poverty and unemployment reduction.

Conclusion- Entrepreneurship is central to the economic growth and development of any nation. The NE program is the resourcefulness of traditional entrepreneurship whose mission is to change the society. The NE program is a sustainable solution for reducing poverty. Adequate attention must be given to the growth of new entrepreneurs.

Keywords: Entrepreneur, poverty alleviation, NE program, Bangladesh.

JEL Codes: M13, N35, P31

\section{INTRODUCTION}

More than billions of people around the world live in the poverty (Singla 2014) and poverty is a major obstacle to the success of social and economic development in many countries (Andrew \& Andrew 1994). The social, economic, demographic, cultural and other significant contributing factors for poverty reduction have implications on the economic development and policy interventions (World Bank 2014). The percentage of people living in extreme poverty globally fell to a new low of 10 percent in 2015 - the latest number available - down from 11 percent in 2013, reflecting steady but slowing progress. The number of people living on less than $\$ 1.90$ a day fell during this period by 68 million to 736 million (World Bank 2018).

There are many countries facing poverty problem. Although the government has taken some policies to alleviate poverty, but until now the problem of poverty has not been fully solved (Singer 2006). Poverty in Bangladesh is becoming widespread and sever. In spite of Bangladesh's vast human resources, the country is known for its low Gross Domestic Product (GDP), low per capita income, high unemployment rate and low industrial utilization capacity (International Labour Organization (ILO), 2013). The poverty rate in Bangladesh fell from 24.3 percent in 2016 to 21.8 percent in 2018, according to the latest data released by the Bangladesh Bureau of Statistics (BBS, 2019). However, an effective way to boost poverty reduction is through entrepreneurship. 
Entrepreneurship is an effective tool for economic development and poverty alleviation in the impoverished and lower-income regions of the world (Mead \& Liedholm 2010). (Ludovick 2013) mentioned in his study that entrepreneurship reduce poverty significantly. Entrepreneurship represents an alternative and potentially effective path to poverty reduction and economic development (Anokhin, Grichnik, \& Hisrich, 2008; and Oghojafor, Olayemi, Okonji, \& Olayiwola, 2011). Entrepreneurship contributes to poverty alleviation when it creates employment through the start-up of new entrepreneurs or the expansion of existing ones. Entrepreneurs can increase social wealth by creating new markets, new industries, new technologies, and new jobs. Entrepreneurs help to increase the living standards for the population (Hoang \& Gimeno 2010). Many studies have tried to answer questions about the identification and setting up of business opportunities (Shane \& Venkataraman 2000). Entrepreneurship is an effective tool (Yunus 2017) which is a close connection with the alleviation of poverty.

New entrepreneurs program is the potential means to improve unemployed individuals by building an understanding of how they can act as entrepreneurs sustainably. NE program which has conceived by Nobel Peace Winner (2006) Professor Muhammad Yunus. To break the cycle of poverty, Grameen social business fund company (GSBFC) provides all kinds of assistance for building a successful NE program in different parts of Bangladesh. This paper describes the procedures and sustainability indicators tools of the NE program.

Many researchers, practitioners, and business societies want to know about the NE program. Even though NE program still a relatively new concept in Bangladesh, but each year many unemployed peoples who join the NE program for creating employment through the business. The primary objective of this study is to explore the poverty alleviation through self-sustaining new entrepreneurs program in Bangladesh.

This paper is structured as follows. In the second section, we discuss the development of the NE program and the reasons why GSBFC engages in NE program. The third section introduces the operation of the NE program and how does it work through the GSBFC in Bangladesh. The fourth section introduces some cases of the NE program, and the fifth section proposes the key success factors of the NE program. Finally, we conclude with some recommendations for the business societies.

\section{THE DEVELOPMENT OF THE NE PROGRAM}

Entrepreneurship can be seen as a pathway to reducing poverty and conflicts in developing countries (Bruton, Ketchen \& Ireland 2013). Reducing unemployment is the most important priority of developed and developing country economies. Entrepreneurs create jobs and increasing the supply of consumables products reducing the unemployment rate (Azhar, Javaid, Rehman \& Hyder 2010). NE program, which is known to create many businesses in the local community in Bangladesh recently. Grameen Social business fund company (GSBFC) is responsible for conducting the NE program to address the unemployment problem in Bangladesh.

The long-term purpose of the NE program is to create positive social and economic impacts and unemployed people are supposed to become entrepreneurs, which in turn creates employment opportunities for themselves as well as for others. Fundamentally, the NE program is a network of unemployed people who contribute their time, expertise, and money to create employment. This support includes providing new entrepreneurs (NE) accesses to advanced financial tools and business networks. This network includes incubation, acceleration, business strategy, financial services, and market.

The new entrepreneurs and the GSBFC both are the business partners. GSBFC invests their investment money into the new entrepreneurs' business and become a managing partner or the manager until back the full investment money to the GSBFC. During this time, new entrepreneurs would take a consolidated monthly salary from his/her business. GSBFC, monitors its investment money only. The objectives of GSBFC are not only to create a job for new entrepreneurs but also to transform a job seeker into a giver and thus create an entrepreneur.

The selling of the shares to the new entrepreneurs, the rule is that the GSBFC will take the original investment money with an additional fixed sum of $20 \%$ on the original investment money. After paying back the original investment money with a $20 \%$ share transfer fee then, GSBFC hand over the full shares/ownership to the new entrepreneurs. This additional amount is called the "share transfer fee". The investment money remains very active during the entire process, making sure that the new entrepreneurs are well prepared for running his business and GSBFC provides all the connections and advice to succeed in new entrepreneurs' businesses. GSBFC is doing a social business and new entrepreneurs business is a profit-making business. Because the GSBFC employed his/her unemployment for creating a small business. 
One revolutionary initiative of Professor Yunus was to establish Grameen Bank (GB) to rescue the poor people from the lenders in Bangladesh. Grameen Bank has since grown into a worldwide movement that has helped over 300 million poor families improve their lives through entrepreneurship. The entrepreneurship model of GB provides an alternative way for reducing poverty (Yunus, Moingeon \& Lehmann 2010) and such a directive is helping the future generations to get rid of their unemployment problems. NE programs as a support system, a safety net for the new entrepreneurs.

The children of the borrowers got support from Grameen bank in the form of education loans to continue their studies and pursue their goals. To ensure their livelihood Professor Yunus came up with the NE program. He tried to deviate their minds from the traditional path of hunting for jobs and tried to make them self-sufficient by making them entrepreneurs. By motivating their entrepreneurial spirit, he tried to make them believe that they are not job seekers but job givers (Khashru 2016) and he came up with a revolutionary idea to solve the unemployment problem. In 2001, Grameen Bank launched the 'Nobin program' and calling the young people who choose that path 'entrepreneurs'. He introduced the social business concept, which emphasizes a combined and organized effort of poverty alleviation through a self-sustaining NE program. It encourages new entrepreneurs to develop, organize and manage a business venture with making a profit.

To help remedy the unemployment and other social problems, Professor Muhammad Yunus created Grameen Social business fund companies (GSBFC). Those are Grameen Telecom Trust (GTT), Grameen Kalyan (GK), Grameen Shakti Shamajik Byabosha (GSSB) and Grameen Trust (GT) for running the NE Program in Bangladesh. In 2013, Yunus Centre, Dhaka, Bangladesh launched the NE Program through the social business design lab which is playing an important role in solving the unemployment problem both locally and globally.

GSBFC focuses on the unemployment children of the Grameen Bank borrower. However, it is a universal application for all young unemployed or underemployed people including the aged or retired people in both developed and developing countries. It can be applied wherever unemployment appears; for example, in crowded cities or thinly populated village, in refugee camps or immigrant communities, and low-income countries or very rich countries (Yunus, 2017).

\section{OPERATION OF THE NE PROGRAM}

Entrepreneurship training are very significant for starting a small business (Elert, Andersson \& Wennberg 2015; Souitaris, Zerbinati \& Al-Laham 2007), training leads to a more realistic view of what it takes to be an entrepreneur (Oosterbeek, Van \& ljsselstein 2010). The NE program maintains selection criteria, training, financial operation, logistics support, monitoring, evaluation, and business sustainability. For the operations of the NE program, the selection criteria and training process is essential, as unemployed people tend to be unaware of their capabilities. As a part of those processes, the field staff of GSBFC organizes an orientation camp in the village. Each of those camps can accommodate 15 to 30 candidates. The candidates can be both boys and girls. Afterward, an experienced camp leader carries out the identification and confidence-building process. During this camp, participants will gain a deeper understanding of the rules and procedures of the NE program and will have the opportunity to ask questions to get a clearer picture of what the program entails. At the camp, selected projects of new entrepreneurs are discussed some questionnaires. These camps usually end with a shortlist of 'potential' entrepreneurs. The following illustrations figure: 1 shows the operation of the NE program. 
Figure 1: Operation of the NE Program

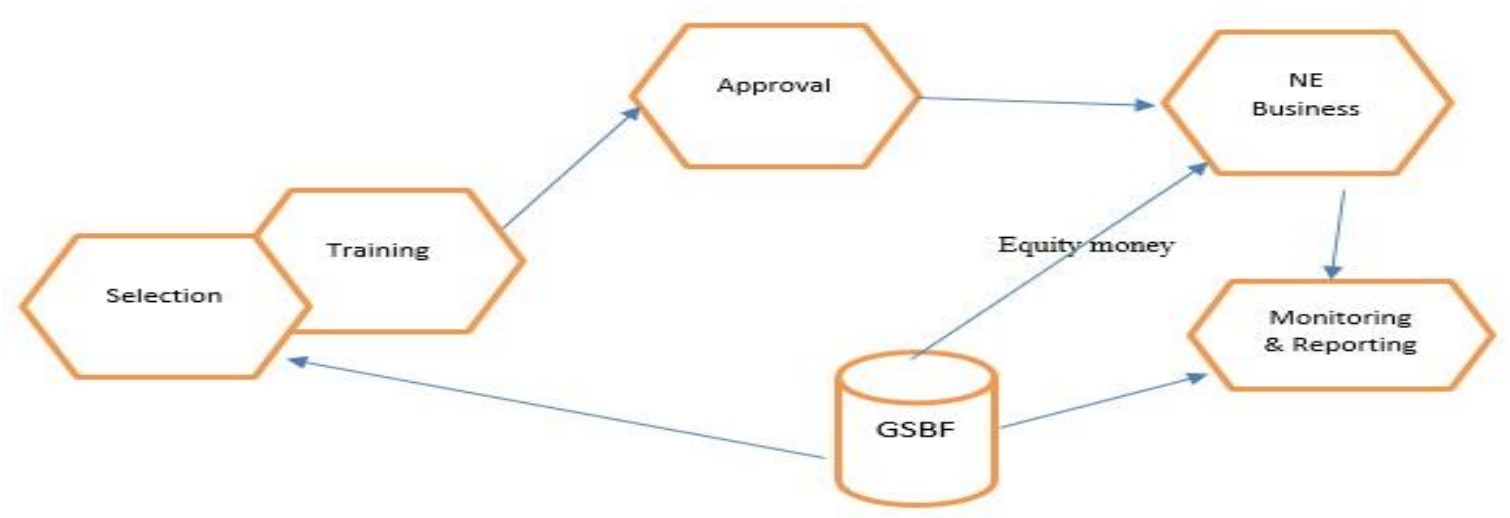

The selected candidate invite to Dhaka to pitch their business plans and ideas at the Business design labs. Each candidate makes a five-minute presentation with financial details in the presence of high-level officials of the GSBFC and ask lots of comments and questions after their pitch. If the board is satisfied, then the business plan gets the approval for investment from GSBFC.

After the approval for equity money, an agreement will be signed between the GSBFC and the new entrepreneurs. There are few clauses included in the agreement to ensure that the new entrepreneurs gradually become a professional and independent businessperson, as follows:

1. I will not look for a job, I will rather give jobs,

2. I will become financially independent through entrepreneurship,

3. I will not commit dishonesty,

4. I will work hard with commitment to expand my business,

5. I will send my children to school,

6. I will become health conscious and will educate my family members about hygiene issues,

7. I will work to minimize unemployment in the area,

8. I will not commit fraud to anyone and will pay a proper salary to my employees,

9. I will not do anything that harms the environment,

10. I will keep a proper record of all financial transactions,

11. I will pay back the investment and make the business mine as soon as possible,

12. I will help others to become an entrepreneur by sharing my experiences and helping them as much as my capabilities,

13. I will contribute to the socio-economic development of my community,

14. I will always do business with happiness.

The next step, GSBFC collecting the financial information daily through the mobile phone via SMS. All the information is accumulated at the central server, which are auto-generates reports for daily, monthly or as desired to GSBFC. The new entrepreneur can also view his business performance information by logging on to the system. If there is a notable difference in the financial and sales figures, the representative of GSBFC to meet the entrepreneur immediately to discuss the issues and creates a solution. 
Finally, GSBFC supports the new entrepreneurs for sustaining the business which is related to the help in professionalism, payback the equity money, business extension, product stock level, new adventures for marketing, quality products, employment opportunity, and social initiators.

\section{SOME CASES OF THE NE PROGRAM}

This research was a focus on NE program innovation, particularly in the established small business of new entrepreneurs, which led to an in-depth study of many cases. According to Patton (1990) \&Yin (2009), a case study is an in-depth investigation of individual groups, institution or phenomena. The researcher uses it because it provided a detailed examination of his study and it was the most appropriate method of collecting data concerning fostering entrepreneurship as a solution to poverty reduction in developing the economy. (Mattar 1994) mentioned that structured interviews set out from standardized questions, whereas in semi-structured interviews, despite the existence of a script with the main topics to be addressed, other questions not contained in the script but deemed pertinent can be asked. Our interviews with the new entrepreneurs are involved in their professional attitude.

In particular, we describe the NE program approach to cultural learning and building sustainable business communities. First, we describe the research setting and method, as our case study uses the qualitative research method that captures the new entrepreneurs' activities of importance to the acculturation process and context. Second, we provide some background information about new entrepreneurs. In conclusion, we outline specific implications and future research directions. This research was to confront conventional literature on NE program innovation with the Grameen Bank experiences implemented by the GSBFC. To test whether the NE program is innovation and to find out if the NE program resembled conventional business model innovation.

This study was carried out in Tangail and Dhaka districts. Tangail is located 100 Kilometer north of Dhaka, the capital city of Bangladesh.There are two case study design was adopted in this study. The study targeted the new entrepreneurs business who are actively involved in the NE program. The field survey was conducted at two branches of the GSBFC, named Sheldon (Tangail) and Jannatul (Dhaka). The following two cases provide the business professional success perspective to the NE program. We focused on the case of Sheldon and Jannatul, a new entrepreneur who has been leading an initiative aimed at increasing the standard of their life through the NE program.

\subsection{Case One}

Sheldon was 19 years old. He was able to study till class eight. He could not continue his studies due to financial problems. His father died when he was ten years old. His mother was a member of Grameen Bank. He has four brothers and sisters with lives his mother. His mother encourages him to contact with the GSBFC for his business investment money. His mother makes the bamboo handicraft item. One day he contacts the GSBF and submits his business proposal for equity money. He takes the training from the field station of GSBF. His business plan was selected for presenting on the design lab in Dhaka. He got USD 625 for the investment money of his business, and he invested more USD 375 from his mother. Sheldon started his business with a total of USD 1000. Now his business capital has increased USD 2000. He makes various bamboo baskets, fruit and flower baskets, hand fan. He is now a professional and successful businessperson. Many traders buy his product directly. The demand for his products has increased accordingly.

In the meantime, he has given back his business equity money to the investor. He created two jobs in his business. After meeting all costs including employees and other expenses, earns the profit USD 100 per month. He provided financial information to the funding company daily through mobile SMS. Sheldon has been a pioneer in this area. He can prepare the financial plan, calculate the daily income expenditure, determine the price of the product, and sell products to the customers by himself. He can write his daily expenditure in the accounts book. He understood how poverty could be overcome by doing the business.

\subsection{Case Two}

Jannatul who is an inspirational entrepreneur. Her mother was a respected borrower member of Grameen Bank. After finished the education, she tried to find a job. She took the tailor training and bought an old machine for cloth sewing. After a long struggle, she is a motivational entrepreneur in her society today.

One day her mother suggested to her for submitting a business plan to the GSBFC. Jannatul contacts with the field office of GSBFC and submitted her business plan. She joined the training camp of GSBFC and selected her business plan for the design lab. Her 
business name was "Irina Fashion Tailors and Boutique House". The proposed business capital was USD 3600 which she invested USD 1800 from herself e and USD 1800 from the GSBFC. After getting the capital money, she starts her business.

After getting the investment money, Jannatul starts her business and receives many orders for making the cloths from the customer. She prepares the daily accounts of her business and provides the financial information to the GSBFC through mobile SMS at the end of the day. Within a few days, her business grows up, and she returned her investment money with share transfer fees to the GSBF within three years. Now Janatul improved her economic condition. Janatul employed two unemployment peoples in her business.

Based on two cases study, we identified many success factors of new entrepreneurs have a significant relationship with the NE program success factors in Bangladesh.

\section{KEY SUCCESS FACTORS OF THE NE PROGRAM}

The NE program has been making vital contributions to economic development by providing Investment money to new entrepreneurs business. We observed there are some barriers to the NE program in Bangladesh such as lack of access to nonGrameen Bank unemployed peoples, payback the investment money, lack of social environment are also seen. These adversely can affect their contribution to more employment creation and poverty reduction. GSBFC, created much employment through the NE program in Bangladesh, shows the statistics:

Table: 1, Statistics of NE Program from 2013 and up to 2018

\begin{tabular}{|c|c|c|}
\hline 1 & Total number of NE projects Presented & 38,588 \\
\hline 2 & Total number of NE projects approved & 38,253 \\
\hline 3 & Total number of new entrepreneurs funded & 35,047 \\
\hline 4 & New entrepreneurs employed of their business & 15,270 \\
\hline 5 & Total employment generation (4+5) & 50,317 \\
\hline
\end{tabular}

This data shows the total number of employment created through the NE program. At the same time, new entrepreneurs created many jobs for unemployment people in their business. In Bangladesh, the impact of small enterprises on specific socio-economic variables such as children's schooling, household nutrition, health, education is traceable (Chowdhury 2007). However, the new entrepreneurs play an important role in the improvement in education, nutrition, and the health condition of their family members. GSBFC properly addressed these aspects, where poor people become entrepreneurs for reducing poverty through the NE program. As a result, unemployment people will be able to stand on their own feet and the NE program will be developed around the world.

Entrepreneurs' business contributes significantly to unemployment and poverty reduction by providing much employment (Dhaliwal, 2016). They make employments growth of the nation by creating new jobs in the short and long-term (Kritikos 2014). It is our understanding that the primary measures of the success of the NE program are the sustainable impact that new entrepreneurs created their employment through the business and created many jobs for others. New entrepreneurs pay back their investment money to the GSBFC properly. However, our observation indicated that the NE program also benefits entrepreneurs in numerous ways.

Moreover, based on our study, certain success factors of the NE program have been identified which come through the NE program daily operations have been discussed below:

Family Background - (Hisrich \& Brush 1987) argued that family background is important to entrepreneurs. In this case, most of the members of Grameen Bank stated the reason for joining the Grameen Bank's micro-credit program to be to improve their life through poverty alleviation and increase their income for a better life through income-generating activities. For running their small business, they take the loan from GB. The children of Grameen Bank borrowers take the business consultancy from their parents for their own business. Sheldon and Jannatul take the business consultancy from their mother accordingly. 
Business strategy - A business strategy is a set of competitive moves and actions that a business uses to attract customers, compete successfully, strengthening performance, achieve organizational and goals outlines how business should be carried out to reach the desired ends (Neuman 2003). According to Namiki (1988) it is very difficult for small businesses to lead in the market where numbers of suppliers already exist. The focus should be on its existence in every way it should remain in the market. According to Joynt \& Welch (1985), it is very hard to manage a growing business because whenever new small business grows it requires more investment and more professional. The expenses of business ultimately increase and it possible that the short-run profit of an organization decreases. Most organizations do not understand the phenomena this circle and go to a low level or stay at a small level. According to Hallberg (2000) in small businesses, the management team is the main factor. According to him, the entrepreneur's trust in the market also plays a vital role in small level business. NE program trains to new entrepreneurs' business strategies. They collect the sales order from their buyers and supply them as per their requirements. Also, if they face any problem with an excess stock of goods, then GSBFC provides them business advice. In our case study, we found, Sheldon and Jannatul followed the business strategy for increasing their sales.

Financial support - (Naudé 2011) had argued that the inability of entrepreneurs to access external and internal financing from banks and other financial institutions contribute to the high failure rates of business start-ups. Most unemployed poor peoples in Bangladesh do not own land, which is another factor of production and cannot access collateral against the loans. Most banks and financial institutions consider youth business start-ups as high-risk ventures, and therefore, decline to invest that venture. Being a developing country and having poor infrastructure, Bangladesh's economy has been operating through an inefficient financial market through which it is almost impossible for the poor to get loans from financial institutions, which require sufficient collateral.

The NE program has innovated a mechanism under which business equity money is providing to the second generation of Grameen Bank borrowers without any collateral. Sheldon and Jannatul presented their business plan on the design lab, which has organized by the funding company. GSBFC provides the business investment money of their business without any collateral. The findings on access to finance influence on the success of NE program start-ups revealed the existence of a positive relationship between GSBFC and the success of them.

Sales and Marketing - A surveillance is conducted by GSBF to verify whether the business is running smoothly of Sheldon and Jannatul. If the customers know that this business is operating by the new entrepreneurs then the customers try to buy the product from the new entrepreneurs business. Some indications of new entrepreneurs' good relationship are:

- Loyal customers buy the product or goods in credit from new entrepreneurs.

- New entrepreneurs' behaviour and honesty are very satisfactory. They can attract new customers.

- Old customers are willing to come to buy more products or services because of trust.

Sheldon and Jannatul used the GSBFC logo to promote their services to customers, and they got many customers. They always improve their service by taking into consideration all the feedback from customers. People come to them because of the uniqueness of their products. They are very creative in giving their services to the customers. All new entrepreneurs have learned from the GSBFC that the most important aspect of a business is not to generate profit but to attract and retain customers

Budgeting and Daily Cash Statements - Financial literacy topics such as record keeping, budgeting, personal finance, and savings were viewed to be more important to lower-income individuals. Record keeping is a fundamental skill a businessperson must possess (Gray, Sebstad, Cohen \& Stack 2009). Budgeting, on the other hand, refers to the expenditure planning and cash flow analysis (Uddin, Chowdhury \& Zakir 2009) which is very important to the success of the business operation and processes (Bragg \& Burton 2006). However, (Torres \& Nichole 2008) found that small business owners are not concerned about budgeting; their concern is more of the cash flow. Sheldon and Jannatul maintain the budget and daily cash statement. They take the training from the NE program on how to prepare the daily cash budget and how to minimize the daily personal expenditures. After accounting for the daily cash budget, they understand about the profit. Sheldon and Jannatul believe that the experience acquired through the NE program has given him the necessary ability and knowledge to maintain financial training.

Legal Compliance - Potential entrepreneurs with weak legal knowledge are usually unable to run their business properly and should need legal assistance to avoid penalties (Levie \& Autio 2011). GSBFC provides the training for Sheldon and Jannatul about the legal transparency of their business.

Good Relations with Suppliers - The relationship between buyer and seller should not be a discrete event and need to see this relationship as an ongoing process (Cannon \& Perreault, 1999; Dwyer, Schurr \& Oh, 1987). Sheldon and Jannatul creates a good 
relationship with suppliers. They maintain the business deal with the suppliers. Suppliers guarantee the best price and quality to retailers to maintain trust among them.

The NE program's success story in the alleviation of poverty in Bangladesh has resulted in widespread attempts of its replication in many other countries.

\section{CONCLUSIONS}

The study concludes that the NE program can contribute to the important role in poverty reduction and social-economic development in Bangladesh. We identified new entrepreneurs' business-related seven success factors, which are related to the NE program in Bangladesh. The most important finding of this case study is that the business skills of NE have a direct relationship with the development of the NE program in Bangladesh. New entrepreneurs become more enthusiastic to initiate their business after taking the training from the NE program. These significant relationships indicate that if the GSBFC can enhance this skill among the more unemployed peoples, it would lead towards the development of the NE program around the world. As a result, unemployed peoples will be able to stand on their own feet and reducing poverty.

This study considered poverty alleviation through the self-sustaining of the NE program. We believe strongly there will be a growing interest in the NE program for two main reasons. First, the corporate business peoples, NGOs or non-profit organizations can sustainably practice the NE program. This practice will be leading many unemployed peoples to create entrepreneurs for reducing their poverty. Secondly, in our conventional practice, NE programs are not engaged in a contest. The objective of GSBFC to reduce poverty through the NE program. The findings in this article have emerged from the field and the specific context for shaping current practice in GSBFC.

\section{REFERENCES}

Azhar, A., Javaid, A., Rehman,M., \& Hyder, A. (2010). Entrepreneurial intentions among business students in Pakistan. Journal of Business Systems, Governance and Ethics, 5(2), 13-21.

Andrew, E. C., \& Andrew J. O. (1994). Unhappiness and unemployment: The Economic Journal, 104(424), 648-659.

Anokhin, S., Grichnik, D., \& Hisrich, R. D. (2008). The journey from novice to serial entrepreneurship in China and Germany: Are the drivers the same? Managing Global Transitions, 6(2), 117-142.

Singer, A. E. (2006). Business strategy and poverty alleviation. Journal of Business Ethics, 66(2-3), 225-231

Bangladesh Bureau of Statistics (BBS) (2019). Dhaka, Bangladesh. www.bbs.gov.bd

Bragg, M. \& Burton, J. (2006). Accounting And Finance For Your Small Business. New Jersey, USA: Wiley.

Bruton, G.D., Ketchen, D.J., \& Ireland, R.D. (2013). Entrepreneurship as a solution to poverty. Journal of Business Venturing, 28(6), 683-689.

Cannon, J. P., \& Perreault, W. D. Jr. (1999). Buyer-seller relationships in business markets. Journal of Marketing Research, 36(4), 439-460.

Chowdhury, M.J.A. (2007). Does the participation in the microcredit programs increase consumption of participating households? The Case of the Grameen Bank in Bangladesh. https://econpapers.repec.org/paper/agsudcmdw/46545.htm

Dwyer, F. R., Schurr, P. H., \& Oh, S. (1987). Developing buyer-seller relationships. Journal of Marketing, 51(2), 11-27.

Dhaliwal, A. (2016). Role of entrepreneurship in economic development. International Journal of Scientific Research and Management, 4(6), 42624269.

Elert, N., Andersson, F., \& Wennberg, K. (2015). The impact of entrepreneurship education in high school on long-term entrepreneurial performance. Journal of Economic Behavior \& Organization, 111, 209-223.

Gray, B., Sebstad, J., Cohen, M., \& Stack, K. (2009). Can financial education change behavior? Lessons from Bolivia and Sri Lanka. Global Financial Education Program Financial Education Outcomes Assessment Working Paper \#4.

Grameen Telecom Trust (GTT). (2010). Social business fund company, Dhaka, Bangladesh., http://gtctrust.com/

Grameen Kalyan (GK). (1996). Social business fund company, Dhaka, Bangladesh., http://www.grameenkalyan-info.org/

Grameen Trust (GT). (1989). Social business fund company, Dhaka, Bangladesh. http://www.grameentrust.org/ 
Grameen Shakti Shamajik Byabosha (GSSB). (2011). Social business fund company, Dhaka, Bangladesh. http://socialbusinesspedia.com Hisrich, R. D., \& Brush, C. (1987). ‘Do women entrepreneurs require different training'? American Journal of Small Business, 12(1), 27-36 Hoang, H., \& Gimeno, J. (2010). Becoming a founder: How founder role identity affects entrepreneurial transitions and persistence in founding. Journal of Business Venturing, 25(1), 41-53.

Hallberg, K. (2000). A market-oriented strategy for small and medium scale enterprises. Working paper series. Washington, D.C.: The World Bank. International Labor Organization (ILO) (2013). Bangladesh: Seeking better employment conditions for better socioeconomic outcomes. https://www.ilo.org/global/research/studies-on-growth-with-equity/WCMS_229105/lang--en/index.htm

Joynt,P., \& Welch, L. (1985). A strategy for small business internalization. International marketing review 2(3), 64-73.

Khahsru, A., MFM. (2016): The Power of Social Business. Dhaka, Bangladesh: Anynna Prokasoni.

Kritikos, A. S. (2014). Entrepreneurs and their impact on jobs and economic growth. IZA World of Labor. https://wol.iza.org/articles/entrepreneursand-their-impact-on-jobs-and-economic-growth/long

Levie, J., \& Autio, E. (2011). Regulatory burden, rule of law, and entry of strategic entrepreneurs: An international panel study. Journal of Management Studies, 48 (6), 1392-1419.

Ludovick, L. S. (2013). Alleviating poverty trough innovation and entrepreneurship. Research Paper, University of Florida, USA.

Mead, D.C., \& Liedholm, C. (2010). The dynamics of micro and small enterprises in developing countries. World Development, 26(1), 61-74.

Mattar, F. (1994). Pesquisa de Marketing: Metodologia, Planeamento, Execução e Análise.São Paulo: Atlas.

N. Namiki. (1988). Export strategies for small business. Journal of Small Business Management, 26(2), 32-37.

Naudé, W. (2011). Entrepreneurship is not a binding constraint on growth and development in the poorest countries, World Development, 39, 3344.

Neuman, L. W. (2003). Social research methods: Qualitative and quantitative approaches. London,UK: Allyn \& Bacon

Oosterbeek, H., Van, P. M., \& ljsselstein, A. (2010). The impact of entrepreneurship education on entrepreneurship skills and motivation. European Economic Review, 54, 442-454.

Oghojafor, B. E. A., Olayemi, O. O., Okonji, P. S., \& Olayiwola, P. O. (2011). Entrepreneurship as an intervention strategy to poverty alleviation in developing economy. Tamkeen, Bahrain.

Patton, M.Q. (1990): Quantitative Evaluation and Research Methods. Oaks, CA: Sage

Shane, S., \& Venkataraman, S. (2000). The promise of entrepreneurship as a field of research. Academy of Management Review, 25(1), 217-226.

Singla, M., L. (2014). Microfinance and economic development in India: Growth and challenges. International Journal of Research in Finance and Marketing, 4(3), 1-13.

Souitaris, V., Zerbinati, S., \& Laham, Al., A. (2007). Do entrepreneurship program raise entrepreneurial intention of science and engineering students? The effect of learning, inspiration and resources. Journal of Firm Venturing, 25, 566-591.

Torres \& N. L. (2008). Budget sense. Entrepreneur, 36(5):98-98

Uddin, M., Chowdhury, R., \& Zakir, A. (2009). Do we need to think more about small business capital budgeting? International Journal of Business Management, 4(1): 112-116.

World Bank (2014). Preventing diarrhea through better water, sanitation and hygiene: exposures and impacts in low- and middle-income countries.

World Bank (2018). Decline of global extreme poverty continues but has slowed.

Yunus, M., Moingeon, B., \& Ortega, L. (2010). Building social business models: Lessons from the Grameen experience. Long range planning 43(2/3), 308-325.

Yunus, M. (2017). A world of Three Zeroes: The New Economics of Zero Poverty, Zero Unemployment, and Zero Net Carbon Emissions. NY, USA: Public Affairs.

Yin, R. (2009). Case Study Research: Design and Methods. Oaks, CA: Sage. 